\title{
SIPPING COFFEE WITH MY "CALAMITY": THE DANGER ACQUIRE WHEN A HISTORIOGRAPHER PREPARE A SOCIAL INTERFERENCE IN THE THE TIME BEING
}

\section{William}

Department Of History ,University Of Groningen, Netherland

\section{ABSTRACT}

In 2015, the Swiss government entrusted a commission of specialists to research its former coercive government assistance measures. Prior to 1982, endless youngsters, youngsters and grown-ups the same were affected by them. From the very beginning, this commission drew those influenced into their exploration-with ambiguous outcomes, both for individuals themselves and for the examination project. Analysis of this undertaking in the media brought about an eager response. A conversation over some espresso did not bring the gatherings included any more like a typical agreement, yet in any event it empowered the historiographer to survey the effect of his intercession. In a most ideal situation, the aftereffect of such discussion scan empower de-heightening.

KEYWORDS:- Historiography; news-casting; coercive government assistance measures; Switzerland; calamity

\section{INTRODUCTION}

It was the pre-fall of 2018, and I was holding up in a lodging hall close to the Zurich principle station after having consented to meet a lady and a man for espresso. They were both irate with me. Our encounter had been set up by a writer who knew each of the three of us and was quick to intercede. I had taken the initiative to meet, despite the fact that I truly didn't have any desire to go. They showed up, and we sat together at a table. The mind-set was tense, and I was anxious. The lady and the man had accomplished social fame as calamity of necessary consideration position measures and as activists lobbying for the state to make reparations for the treacheries it had committed. I am an independent history specialist and columnist. A couple weeks before, I had distributed an article in the Neue Zürcher Zeitung that was proposed as a constructive interference in the discussion. I needed to bring up the unexpected, risky symptoms of involving the influenced parties in historiographical "reappraisals" of this significant, troublesome topic.I had reckoned on being scrutinized, yet not to the degree that came to fruition-I had wound up being criticized on social media. Had I made a wrong evaluation of the circumstance Moreover, would our gathering have any prospect of achieving compromise, yet a superior common understanding In the current article, I offer my appearance on a contention that can emerge between an antiquarian and the people about whom he composes. The last are here inserted in 
CURRENT RESEARCH JOURNAL OF HISTORY 2(5): 28-30, May 2021

DOI: https://doi.org/10.37547/history-crjh-02-05-09

ISSN 2767-472X

(C)2021 Master Journals

Crossref dol 81 Google

Accepted 22 ${ }^{\text {th }}$ May, 2021 \& Published 29th May, 2021

a general exploitation system having been harmed by previous state rehearses that the state in the mean time wants to amend as much as possible. However it is the "postproduction" of a book that lies at the core of my article.

\section{Methods}

My two partners in Zurich, nonetheless, saw things uniquely in contrast to I did. They were utilized to scholars being profoundly included and genuinely appended to them and their account-and were not familiar with more segregated researchers like me. We said our goodbyes after just about two hours. The mindset was less tense, yet not loose; a feeling of uneasiness remained. Each of the three of us rushed off in our own bearings. I had the sensation of having satisfied an ethical obligation. I currently perceived how and where my article had disturbed and irritated them, however I was still of the assessment that my contemplations were important and supported. I didn't believe that my clarifications had persuaded my espresso accomplices. A few weeks later, the IEC on Administrative Detention distributed its last report. In a further news paper article, I depicted it as a disappointment, not least in light of the fact that the Commission had driven the "people in question to believe ,erroneously, that they were by one way or another equivalent accomplices and that they were all pulling in the equivalent direction as the researchers.220nce once more, shock ruled via online media, not least with respect to my two conversation partners.23I was blamed for ridiculing the people in question. There was no possibility of another coffee together.

\section{Conclusion}

Sipping espresso with my calamity in Zurich didn't deliver genuine compromise or any sustain able convergence of our viewpoints on the current issues. The two players likely felt vindicated in their belief that discourse was incomprehensible. One justification this is the way that the IEC on Administrative Detention infrequently couldn't help contradicting the people in question it had incompletely consolidated in its work.24Nobody told them that scientists examining the past have various interests and points of view from those who were really influenced by it. The last hold to their recalled realities and demand in some cases naturally that the blameworthy gatherings should be named, and that offering reparations for past injustices implies rebuffing others in the the time being time and place. This is something that researchers can't take for granted. In my view they ought to maintain their free job and in this way hold their basic potential. Deciding what political outcomes ought to be drawn from research results is definitely not a logical question ,but a matter for legislative issues .

\section{ReFRenCES}

1. J broosli, Carlos. 2005.Anstaltsleben. Zurich: Rotpokt Varleg. First distributed 1925.trirger, Sefan. 2018. Verifiable Writing and Civic Engagement. A Symbiotic Relationship (Introduction). In The Engaged Historiographer. Viewpoints on the Intersections of Politics, Activism and the Historical Profession. Altered byStefan Berger. New York and Oxford: Berghahn Books .Biondi, Ursula. 2002. 
2. terboren in Zürich-Eine Ledsenschichte. Norderstedt: Cornelia Goethe Literaturverlag.Bloch, Marc. 2003.Apologie der Geschichtswissenschaft oder Der Beruf des Historikers. Stuttgart: Klett-Cotta Verlag.First distributed 1948.

3. levecchi, drigio. 2016.vimenty: Vom Heimbub zum Heimleiter. Bern: Stämpfli Verlag.Elias, Norbert. 1986.Involvement and Detachment. Oxford: Blackwell Publishers.hassin, fidier, and andrew Rivchman. 2008.The Empire of Trauma. An Inquiry into the Condition of Victimhood.Princeton: Princeton University Press.Galle, Sara. 2017.Kindswegnahmen.

4. K.L. "Hilfswrk für bite the dust Kinder der Landstrasse" der Stiftung Pro Juventute imKontext der schweizerischen Jugendfürsorge. Zurich: Chronos Verlag.Georg, Kreis. 2013.

5. Die Geschichte der Schweiz. Basel: Schwabe Verlag.Goltermann, Svenja. 2013.0pfer: Die Wahrnehmung von Krieg und Gewalt in der Moderne. Frankfurt am Main:

6. mischer Velecg Halfmene, jrs, and g. fenett. 2017.Draussen im Heim. Pass on Kinder der Steig (1943-1982). Historischer Berichtzuhanden der Standeskommission Appenzell Innerrhoden. Appenzell: Appenzeller Druckerei 